\title{
PENGARUH TINGKAT KESEHATAN BANK MENURUT RISK BASED BANK RATING TERHADAP KINERJA KEUANGAN DENGAN GOOD CORPORATE GOVERNANCE SEBAGAI VARIABEL PEMODERASI PADA BANK UMUM SYARIAH DAN UNIT USAHA SYARIAH DI INDONESIA
}

\begin{abstract}
Abstrak
Usaha syariah di Indonesia cukup potensial untuk berkembang, terutama adalah perbankan syariah. Hal ini Nampak pada Tahun 2008 ketika krisis melanda, nampaknya sektor perbankan syariah masih mampu bertahan dengan baik. Oleh karena itu manajemen perbankan syariah harus dapat selalu meningkatkan kualitas layanan kepada masyarakat sehingga mampu bekerja secara optimal. Sehingga perbankan syariah harus mengelola tingkat kesehatannya. Penelitian ini bertujuan untuk melihat pengaruh tingkat kesehatan perbankan syariah terhadap kinerja keuangan dengan variable intervening good corporat governance. dengan metode path analisis terhadap Bank Umum dan Unit Usaha Syariah ditemukan bahwa secara langsung variable CAR berpengaruh terhadap GCG dan GCG berpengaruh terhadap ROA. Sedangkan GCG hanya mampu momoderasi pegaruh BOPO terhadap ROA sebagai indicator kinerja keuangan perbankan syariah. Sehingga bank Umum Syariah dan Unit Usaha Syariah harus mampu mengelola rasio biaya opersional terhadap pendapatan operasional dengan lebih baik. Karena semakin rendah BOPO berarti semakin efisien bank tersebut dalam mengendalikan biaya operasionalnya, dengan adanya efisiensi biaya maka keuntungan yang diperoleh bank akan semakin besar.
\end{abstract}

Kata Kunci : Good Corporate Governance, Kinerja Keuangan, Kesehatan Perbankan Syariah

\section{PENDAHULUAN}

Krisis ekonomi yang melanda Indonesia Tahun 1998 merupakan pukulan yang berat bagi perekonomian Indonesia. Banyak lembaga keuangan termasuk perbankan mengalami kesulitan keuangan pada waktu itu. Kualitas aset perbankan turun secara drastis sementara sistem perbankan diwajibkan untuk terus memberikan imbalan kepada depositor sesuai dengan tingkat suku bunga pasar. Akan tetapi pada krisis tersebut perbankan syariah dapat bertahan. Hal ini terlihat dari relatif rendahnya penyaluran pembiayaan yang bermasalah (Non Performing Financing) dan tidak terjadinya negative spread.

Perbankan syariah berpotensi tumbuh subur di Indonesia, karena penduduk muslim Indonesia mencapai 88,2 persen pada Tahun 2010 (Rahab, 2008). Pertumbuhan luar biasa dari bank syariah ini karena adanya keyakinan bahwa mereka akan memainkan peran penting dalam perekonomian masa depan. Indonesia kini telah menempati peringkat ketiga dunia dari jumlah kelembagaan, dan total aset syariah peringkat sembilan dunia, dengan aset sebesar USD35,63 miliar atau pangsa pasar dunia 2,1 persen(Adila, 2015).

Beroperasinya perbankan syariah di Indonesia sejak tahun 1992 merupakan fase awal dalam memperkenalkan kepada masyarakat suatu sistem yang mengaplikasikan mekanisme dan produk yang

Korespondensi dengan penulis: 
berlandaskan prinsip syariah serta menggunakan sistem bagi hasil, kehadiran bank syariah memperoleh tanggapan yang semakin baik di masyarakat. Perkembangan bank syariah mulai terasa sejak dilakukan perubahan terhadap UU No. 7/1992 menjadi UU No. 10/1998 yang memberikan landasan operasi yang lebih jelas bagi bank syariah. Kehadiran Unit Usaha Syariah memungkinkan konsumen untuk dapat memperoleh fasilitas pelayanan produk syariah yang semakin bervariasi.

Perkembangan Bank Umum Syariah dan Unit Usaha Syariah harus disertai dengan peningkatan kualitas layanan kepada masyarakat. Kualitas layanan tersebut dapat dilihat dari tingkat kesehatan BUS ataupun UUS, karena pada dasarnya kegiatan utama dari perbankan adalah menghimpun dana dari masyarakat dan menyalurkannya kembali dalam bentuk pembiayaan. Oleh karena itu, selama ini parameter pengukuran kualitas atau kesehatan bank dilakukan dengan metode CAMELS (Capital, Asset Quality, Management, Earning, Liquidity dan Sensitivity of Risk). Akan tetapi dalam perkembangannya, Muhari (2013) menyarankan komponen kuantitatif CAEL pada metode CAMELS perlu dilakukan peninjauan ulang dalam menentukan bobot komponen efisiensi (Biaya Operasional terhadap Pendapatan Operasional) agar pihak perbankan dapat beroperasi lebih efisien dan menerapkan prinsip kehati-hatian.

Parameter pengukuran kesehatan bank terbaru berdasarkan Peraturan Otoritas Jasa Keuangan (OJK) No. 8/POJK.03/2014(OJK, 2013), menetapkan bahwa pengukuran kesehatan perbankan menggunakan metode Risk Based Bank Rating. Penilaian tersebut meliputi faktor profil risiko (risk profile), Good Corporate Governance, rentabilitas (earnings), dan permodalan (capital).

Peningkatan FDR (Financing to Deposit Ratio) berpengaruh positif terhadap peningkatan ROA. Penurunan BOPO (Biaya Operasional terhadap Pendapatan Operasional) berpengaruh positif terhadap peningkatan ROA. Penelitian Usman (2003) menunjukkan adanya pengaruh positif signifikan antara BOPO terhadap ROA. Hasil penelitian Usman (2003) bertentangan dengan penelitian yang dilakukan oleh Heriyanto (2009) dan Edhi (2009) yang menunjukkan adanya pengaruh yang negatif signifikan antara BOPO terhadap ROA, sehingga perlu dilakukan penelitian lanjutan. Sedangkan peningkatan dan penurunan CAR (Capital Adequacy Ratio) tidak sejalan dengan peningkatan atau penurunan ROA. Sehingga perlu dilakukan penilaian dari berbagai aspek mengenai faktor-faktor yang mempengaruhi kinerja perbankan syariah dan unit usaha syariah yang tercermin dari ROA. Penilaian dilakukan dari berbagai aspek baik finansial maupun non finansial.

Pengaruh faktor finansial maupun non finasial terhadap kinerja keuangan perbankan syariah dan unit usaha syariah dalam hal ini diwakili dengan ROA (Return On Asset). Sebagai lembaga yang dalam kegiatanya menggunakan dana dari masyarakat, bank dituntut untuk mempertahankan dan meningkatkan kinerjanya. Archer dan Rifaat (2009) menemukan bahwa kurangnya manajemen modal (pengelolaan kecukupan modal) dan penerapan Good Corporate Governance menyebabkan bank Islam di Inggris, Malaysia, Yordania, dan Qatar menempatkan investasi bagi hasil sebagai modal sehingga likuiditas bank tersebut bermasalah. Penemuan tersebut didukung oleh Dincer, et al, (2011) menemukan bahwa perubahan peraturan perbankan mengenai kecukupan modal dan pengendalian fungsi internal pasca krisis 2001, sektor perbankan mengalami peningkatan profitabilitas bahkan pada bank swasta deposit memiliki pangsa pasar kredit, total aset, dan deposito perbankan terbesar. Kedua penelitian tersebut diketahui bahwa terdapat pengaruh Good Corporate 
Governance terhadap kinerja keuangan perbankan.

Sesuai dengan Peraturan Otoritas Jasa Keuangan (OJK) Nomor 8/POJK.03/2014, penerapan Good Corporate Governance sangat diperlukan dalam mendukung kinerja perbankan syariah. Penilaian dilakukan terhadap manajemen Bank Umum Syariah dan Unit Usaha Syariah atas pelaksanaan prinsip-prinsip Good Corporate Governance. Sehingga, berdasarkan permasalahan di atas, penelitian ini berfokus pada analisis hubungan antara beberapa variabel yang mempengaruhi kinerja keuangan yang tercermin dalam Return On Asset (ROA). Dimana Return On Asset akan meningkat apabila kesehatan bank juga meningkat yang diwakili oleh risiko profil, rentabilitas, dan permodalan. Tujuan dari penelitian ini adalah untuk mengetahui pengaruh kesehatan bank menurut Risk-based Bank Rating terhadap kinerja perbankan syariah dan unit usaha syariah dengan Good Corporate Governance sebagai variabel intervening. Penelitian ini mencoba merumuskan masalah penelitian sebagai berikut:

1. Apakah pengaruh Non Performing Financing (NPF) terhadap kinerja keuangan Bank Umum Syariah dan Unit Usaha Syariah yang diukur dengan Return on Asset (ROA)?

2. Apakah pengaruh Financing to Deposit Ratio (FDR) terhadap kinerja keuangan Bank Umum Syariah dan Unit Usaha Syariah yang diukur dengan Return on Asset (ROA)?

3. Apakah pengaruh Net Interest Margin (NIM) terhadap kinerja keuangan Bank Umum Syariah dan Unit Usaha Syariah yang diukur dengan Return on Asset (ROA)?

4. Apakah pengaruh Beban Operasional terhadap Pendapatan Operasional (BOPO) terhadap kinerja keungan Bank Umum Syariah dan Unit Usaha Syariah yang diukur dengan Return on Asset (ROA)?

5. Apakah pengaruh Capital Adequacy Ratio (CAR) terhadap kinerja keunagan Bank Umum Syariah dan Unit Usaha Syariah yang diukur dengan Return on Asset (ROA)?

6. Mampukah Good Corporate Governance (GCG) memoderasi pengaruh tingkat kesehatan bank terhadap kinerja keuangan Bank Umum Syariah dan Unit Usaha Syariah yang diukur dengan Return on Asset (ROA)?

\section{TINJAUAN PUSTAKA}

\section{Return On Asset (ROA)}

Tujuan perusahaan salah satunya adalah untuk memaksimalkan "earning per share" nya. Untuk mengukur keberhasilan suatu manajemen dalam meraih tujuan tersebut, return dan risk dapat digunakan sebagai ukuran keberhasilan suatu perusahaan, yaitu dengan menganalisis laporan keuangan perusahaan tersebut. Hal di atas juga berlaku untuk perusahaan yang bergerak di bidang perbankan (Mawardi, 2005).

Menurut Hempel (1986), return diukur dengan menggunakan profitability analysis, sedangkan risk diukur dengan menggunakan variabilitas sales, cost, dan diversifikasi portofolio. Secara garis besar, dapat disimpulkan bahwa return yang tinggi dapat dicapai dengan menanggung resiko yang tinggi pula. Dalam perbankan, besar kecilnya return dan risk yang melekat tercermin dalam laporan keuangannya.

Menurut Bank Indonesia Return On Asset (ROA) merupakan perbandingan antara laba sebelum pajak dengan rata-rata total aset dalam satu periode (SE. Intern BI, 2004). Return on Asset (ROA) dipilih sebagai indikator pengukur kinerja keuangan perbankan adalah karena Return on Asset digunakan untuk mengukur

PENGARUH TINGKAT KESEHATAN BANK MENURUT RISK BASED BANK RATING TERHADAP KINERJA KEUANGAN DENGAN GOOD CORPORATE GOVERNANCE SEBAGAI VARIABEL PEMODERASI PADA BANK UMUM SYARIAH DAN UNIT USAHA SYARIAH DI INDONESIA 
efektifitas perusahaan dalam menghasilkan keuntungan dengan memanfaatkan aktiva yang dimilikinya. Semakin besar Return on Asset menunjukkan kinerja keuangan yang semakin baik, karena apabila Return on Asset meningkat, berarti profitabilitas perusahaan meningkat, sehingga dampak akhirnya adalah peningkatan profitabilitas yang dinikmati oleh pemegang saham (Husnan, 1998).

\section{Non Performing Financing (NPF)}

Tingkat kelangsungan usaha bank berkaitan erat dengan aktiva produktif yang dimilikinya, oleh karena itu manajemen bank dituntut untuk senantiasa dapat memantau dan menganalisis kualitas aktiva produktif yang dimiliki. Kualitas aktiva produktif menunjukkan kualitas asset sehubungan dengan risiko kredit yang dihadapi oleh bank akibat pemberian kredit dan investasi dana bank.

Pada bank syariah istilah Non Performing Loan diganti Non Performing Finance (NPF) karena dalam syariah menggunakan prinsip pembiayaan. NPF merupakan tingkat risiko yang dihadapi bank. NPF adalah jumlah kredit yang bermasalah dan kemungkinan tidak dapat ditagih. Semakin besar nilai NPF maka semakin buruk kinerja bank tersebut, (Muhamad, 2005). Mulyono (1995), juga mengungkapkan bahwa Non Performing Financing (NPF) adalah rasio yang digunakan untuk mengukur kemampuan manajemen bank dalam mengelola kredit bermasalah, yang dapat dipenuhi dengan aktiva produktif yang dimiliki oleh suatu bank. Kredit dalam hal ini adalah kredit yang diberikan kepada pihak ketiga dan tidak termasuk kredit kepada bank lain.

Menurut Edhi (2009) dan Heriyanto (2009) NPF berpengaruh negatif terhadap profitabilitas (ROA) perbankan. Semakin tinggi NPF maka semakin menurun kinerja atau profitabilitas perbankan. Agar kinerja bank meningkat, maka setiap bank harus menjaga NPF-nya di bawah 5\%.

\section{Financing to Deposit Ratio (FDR)}

Dalam perbankan konvensional menggunakan istilah Loan to Deposit Ratio (LDR), sedangkan pada perbankan syariah menggunakan Financing to Deposit Ratio (FDR). Arthesa (2009), Financing to Deposit Ratio merupakan rasio yang digunakan untuk mengukur likuiditas suatu bank dalam membayar kembali penarikan dana yang dilakukan deposan dengan mengandalkan kredit yang diberikan sebagai sumber likuiditasnya, yaitu dengan cara membagi jumlah kredit yang diberikan oleh bank terhadap dana pihak ketiga.

Semakin tinggi FDR maka semakin tinggi dana yang disalurkan ke dana pihak ketiga. Dengan penyaluran dana pihak ketiga yang besar maka pendapatan bank akan semakin meningkat, sehingga FDR berpengaruh positif terhadap ROA (Gelos, 2006). Besarnya FDR mengikuti perkembangan kondisi ekonomi Indonesia, dan sejak akhir tahun 2001 bank dianggap sehat apabila besarnya FDR antara 80\% sampai dengan 110\% (Nusantara, 2009).

\section{Net Interest Margin (NIM)}

Pada Bank Umum Syariah Net Interest Margin (NIM) diwakili dengan Net Operating Margin (NOM) yang menunjukkan kemampuan bank dalam mengelola penyaluran pembiayaan kepada nasabah dan biaya operasionalnya sehingga kualitas aktiva produktif terjaga dam mampu membuat peningkatan pendapatan. 
Pengukurannya dapat dilihat dari perbandingan besarnya pendapatan operasional setelah dikurangi dana bagi hasil dan biaya operasional dengan rata-rata aktiva produktif.

Menurut Tainio (2000), secara umum kinerja bank diukur dengan menggunakan variabel pertumbuhan pangsa pasar, variabel profitabilitas dan variabel rate on return. Kinerja bank menurun atau meningkat ditentukan oleh kombinasi faktor lingkungan, strategi dan struktur. Net Interest Margin (NIM) berdasarkan peraturan BI No.5/2003, sebagai salah satu proksi dari resiko pasar adalah suku bunga, dengan demikian rasio pasar dapat diukur dengan selisih antara suku bunga pendanaan (funding) dengan suku bunga pinjaman diberikan (lending) atau dalam bentuk absolute, yang merupakan selisih antara total biaya bunga pendanaan dengan total biaya bunga pinjaman. Menurut Surat Edaran Bank Indonesia No 6/23/DPNP tanggal 31 Mei 2004, Net Interest Margin (NIM) adalah perbandingan antara pendapatan bunga bersih terhadap rata-rata aktiva produktifnya.

Rasio Net Interest Margin (NIM) ini digunakan untuk mengukur kemampuan manajemen bank dalam mengelola aktiva produktifnya untuk menghasilkan pendapatan bunga bersih. Peneliti terdahulu yang menggunakan variable NIM sebagai pengukur kesehatan bank antara lain Sugianto, et, al, (2002) dan Januarti (2002) hasil penelitiannya menunjukkan bahwa NIM mampu digunakan sebagai indikator untuk mengukur tingkat kesehatan bank. Sementara Usman (2003) dalam penelitiannya menunjukkan bahwa NIM berpengaruh positif terhadap ROA dikarenakan ROA dipengaruhi oleh laba.

\section{Biaya Operasional terhadap Pendapatan Operasional (BOPO)}

BOPO adalah rasio perbandingan antara biaya operasional dan pendapatan operasional. Rasio biaya operasional digunakan untuk mengukur tingkat efisiensi dan kemampuan bank dalam melakukan kegiatan operasi (Dendawijaya, 2009). Semakin rendah BOPO berarti semakin efisien bank tersebut dalam mengendalikan biaya operasionalnya, dengan adanya efisiensi biaya maka keuntungan yang diperoleh bank akan semakin besar.

Penelitian yang dilakukan Mawardi (2005), menyimpulkan bahwa BOPO berpengaruh negatif terhadap kinerja bank yang diproksikan dengan ROA. Hal ini menunjukkan bahwa semakin besar perbandingan total biaya operasional dengan pendapatan operasional akan berakibat turunnya ROA. Hal senada diungkapkan Usman (2003) dalam penelitiannya menunjukkan bahwa BOPO berpengaruh signifikan terhadap laba bank sehingga diprediksi BOPO juga mempunyai pengaruh yang signifikan terhadap ROA karena ROA dipengaruhi oleh laba. Penelitian Ghozali (2007) pada Bank syariah Mandiri menjelaskan bahwa Variabel BOPO berhubungan positif dan signifikan hal ini disebabkan dengan adanya penambahan cabang baru dan promosi dapat mempengaruhi tingkat profitabilitas periode Januari 2004 - Oktober 2006.

\section{Capital Adequacy Ratio (CAR)}

Peranan modal sangat penting karena selain digunakan untuk kepentingan ekspansi, juga digunakan sebagai "buffer" untuk menyerap kerugian kegiatan usaha. Menurut Muljono (1999), untuk mengukur kemampuan permodalan menggunakan primary ratio, capital ratio, dan Capital Adequacy Ratio (CAR). Masih

PENGARUH TINGKAT KESEHATAN BANK MENURUT RISK BASED BANK RATING TERHADAP KINERJA KEUANGAN DENGAN GOOD 
menurut Muljono (1999), Capital Adequacy Ratio (CAR) adalah suatu rasio yang menunjukkan sampai sejauh mana kemampuan permodalan suatu bank untuk mampu menyerap risiko kegagalan kredit yang mungkin terjadi sehingga semakin tinggi angka rasio ini, maka menunjukkan bank tersebut semakin sehat begitu juga dengan sebaliknya. Pengertian lain dari Peraturan Bank Indonesia, CAR (Capital Adequacy Ratio) adalah rasio yang memperlihatkan seberapa besar jumlah seluruh aktiva bank yang mengandung resiko (kredit, penyertaan, surat berharga, tagihan pada bank lain) ikut dibiayai dari modal sendiri disamping memperoleh dana-dana dari sumber-sumber diluar bank.

Angka rasio CAR ditetapkan oleh Bank Indonesia sebesar minimal 8\%, jika rasio CAR sebuah bank berada dibawah $8 \%{ }^{26}$, berarti bank tersebut tidak mampu menyerap kerugian yang mungkin timbul dari kegiatan usaha bank, kemudian jika rasio CAR di atas $8 \%$ menunjukkan bahwa bank tersebut semakin solvable. Dengan semakin meningkatnya tingkat solvabilitas bank, maka secara tidak langsung akan berpengaruh pada meningkatnya kinerja bank, karena kerugian-kerugian yang ditanggung bank dapat diserap oleh modal yang dimiliki bank tersebut.

\section{Good Corporate Governance (GCG)}

Menurut Bank Dunia, GCG adalah aturan, standar dan organisasi di bidang ekonomi yang mengatur perilaku pemilik perusahaan, direktur, dan manajer serta perincian dan penjabaran tugas dan wewenang serta pertanggungjawabannya kepada investor (pemegang saham dan kreditur). Tujuannya untuk menciptakan sistem pengendaliaan dan keseimbangan (checkand balances) untuk mencegah kemungkinan penyalahgunaan sumber daya perusahaan dan tetap mendorong terjadinya pertumbuhan perusahaan.

Peningkatan nilai perusahaan merupakan salah satu cara perusahaan untuk meningkatkan kesejahteraan para pemegang saham (Sulistyowati,2010). Kesejahteraan para pemegang saham dapat dicapai apabila perusahaan mampu beroperasi untuk memperoleh keuantungan yang telah ditargetkan (Wijayanti, 2011). Syakhroza (2004), mendefinisikan bahwa GCG sebagai suatu mekanisme tata kelola organisasi secara baik dalam melakukan pengelolaan sumber daya organisasi secara efisien, efektif, ekonomis ataupun produktif dengan prinsip-prinsip keterbukaan, akuntabilitas, pertanggungjawaban, independen, dan adil dalam rangka mencapai tujuan organisasi.

Organization forEconomic Co-Operation and Development(OECD) mendefinisikan GCG dengan sekumpulan hubungan antara pihak manajemen perusahaan, board, pemegang saham dan pihak lain yang mempunyai kepentingan dengan perusahaan. Dalam GCG disyaratkan adanya struktur, perangkat untuk mencapai tujuan dan pengawasan atas kinerja. Implementasi GCG yang baik dapat memberikan perangsang atau insentif yang baik bagi board dan manajemen untuk mencapai tujuan yang merupakan kepentingan bersama.

Sedangkan menurut Peraturan Otoritas Jasa Keuangan Nomor 8/Pojk.03/2014, Good Corporate Governance digunakan sebagai salah satu faktor untuk menilai kesehatan Bank Umum Syariah dan Unit Usaha Syariah. Penilaian terhadap pelaksanaan Good Corporate Governance dinilai dalam suatu governance system yang terdiri dari 3 (tiga) aspek governance, yaitu governance structure, governance process, dan governance outcome. Ditambahkan dalam Surat Edaran Bank Indonesia No. 12/13/DPbS, pelaksanaan GCG pada perbankan syariah 
harus berlandaskan lima prinsip dasar, yaitu transparency, accountability, responsibility, professional, dan fairness.

Selanjutnya penilaian atas pelaksanaan GCG terhadap Bank Umum Syariah dilakukan atas sebelas faktor sebagai berikut.

a. Pelaksanaan tugas dan tanggung jawab Dewan Komisaris.

b. Pelaksanaan tugas dan tanggung jawab Direksi.

c. Kelengkapan dan pelaksanaan tugas Komite.

d. Pelaksanaan tugas dan tanggung jawab Dewan Pengawas Syariah.

e. Pelaksanaan Prinsip Syariah dalam kegiatan penghimpunan dana dan penyaluran dana serta pelayanan jasa.

f. Penanganan benturan kepentingan.

g. Penerapan fungsi kepatuhan.

h. Penerapan fungsi audit intern.

i. Penerapan fungsi audit ekstern.

j. Batas Maksimum Penyaluran Dana.

k. Transparansi kondisi keuangan dan non keuangan BUS, laporan pelaksanaan GCG serta pelaporan internal

Sedangkan penilaian atas pelaksanaan GCG terhadap Unit Usaha Syariah dilakukan atas lima faktor sebagai berikut.

a. Pelaksanaan tugas dan tanggung jawab Direktur UUS.

b. Pelaksanaan tugas dan tanggung jawab Dewan Pengawas Syariah.

c. Pelaksanaan Prinsip Syariah dalam kegiatan penghimpunan dana dan penyaluran dana serta pelayanan jasa.

d. Penyaluran dana kepada nasabah pembiayaan inti dan penyimpanan dana oleh deposan inti.

e. Transparansi kondisi keuangan dan non keuangan UUS, laporan pelaksanaan GCG serta pelaporan internal.

Bank Umum Syariah dan Unit Usaha Syariah diharuskan melakukan self assessment terhadap kinerja perusahaannya. Self assessment dilakukan terhadap faktor-faktor yang disebutkan di atas dengan bobot yang sudah ditentukan oleh Bank Indonesia untuk memperoleh nilai komposit pelaksanaan GCG.

Penilaian terhadap GCG tersebut digunakan untuk meyakinkan para pemegang kepentingan. Schleifer dan Vishny (1977) menyatakan bahwa mekanisme yang berkaitan untuk meyakinkan para pemilik modal dalam memperoleh return yang sesuai dengan investasi yang telah ditanam adalah good corporate governance. Dengan GCG, pemegang saham mayoritas tidak dapat memanfaatkan dan mengambil alih hak-hak dari pemegang saham minoritas (Gugler \& Yurtoglu 2003). Berdasarkan hasil penelitian Halviani (2014), Good Corporate Governance sebagai variabel moderasi dapat memperkuat hubungan antara ROA terhadap DPR.

PENGARUH TINGKAT KESEHATAN BANK MENURUT RISK BASED BANK RATING TERHADAP KINERJA KEUANGAN DENGAN GOOD CORPORATE GOVERNANCE SEBAGAI VARIABEL PEMODERASI PADA BANK UMUM SYARIAH DAN UNIT USAHA SYARIAH DI INDONESIA 
Model Penelitian

Berdasarkan telaah pustaka yang sudah dilakukan di atas, maka kerangka pemikiran dari penelitian ini adalah sebagai berikut. Penulis menggunakan model jalur (path analysis).

\section{Hipotesis}

Kinerja keuangan Bank Umum Syariah maupun Unit Usaha Syariah dapat mempengaruhi kepercayaan masyarakat terhadap bank tersebut. Karena pada dasarnya penilaian masyarakat dilihat dari ukuran tersirat seperti fasilitas, pelayanan dan tingkat keuntungan. Sehingga sebagai lembaga yang dalam kegiatanya menggunakan dana dari masyarakat, bank dituntut untuk mempertahankan dan meningkatkan kinerjanya.

Terdapat beberapa hal yang berkaitan dengan kinerja perbankan syariah yang diproksikan dengan Return On Asset (ROA). Faktor-faktor yang dianalisis di atas, terdiri dari NPF, FDR, BOPO, NIM, dan CAR. Sedangkan untuk variabel intervening adalah GCG. Berdasarkan argumentasi di atas, dapat dirumuskan hipotesis sebagai berikut:

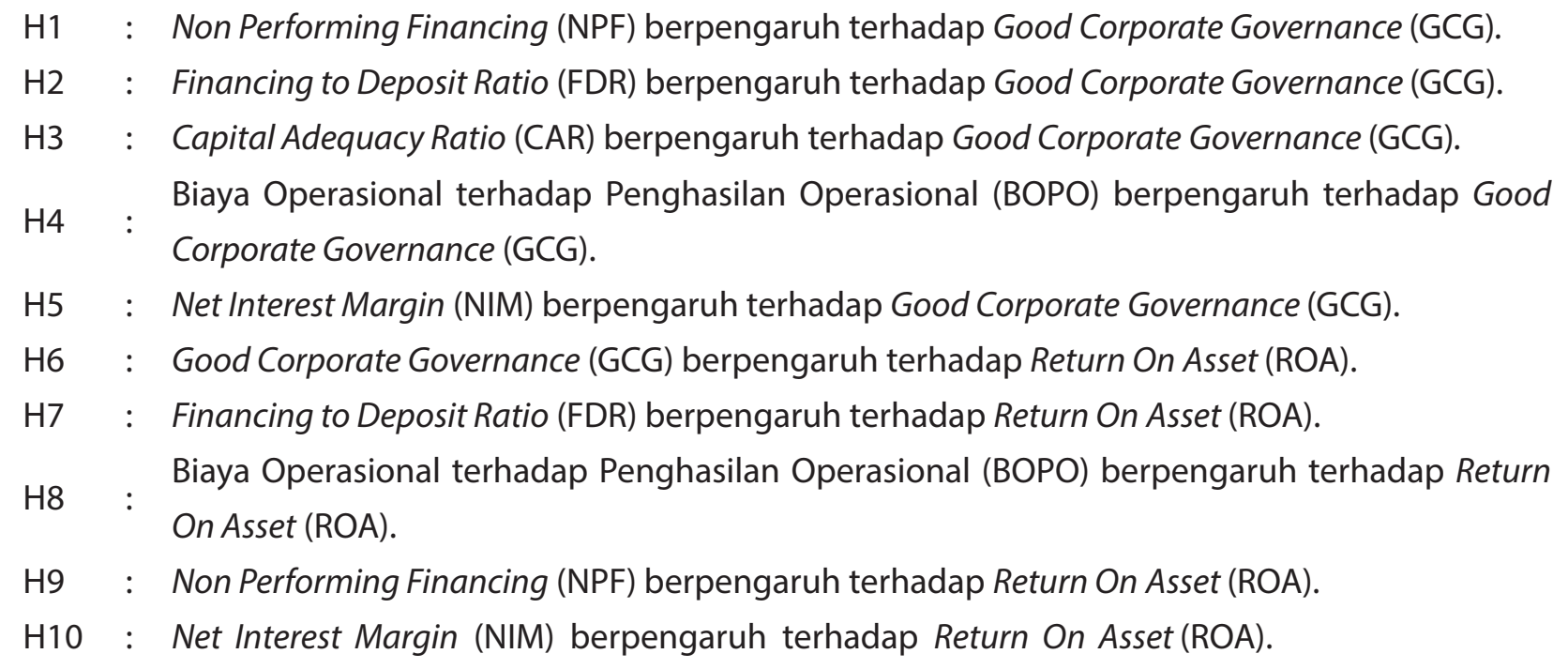

\section{METODOLOGI PENELITIAN}

\section{Populasi dan Sampel}

Populasi dari penelitian ini adalah Bank Umum Syariah dan Unit Usaha Syariah di Indonesia. Penelitian menggunakan purposive sampling untuk menentukan sampel. Kriteria yang digunakan untuk menentukan sampel adalah sebagai berikut.

1. Bank Umum Syariah dan Unit Usaha Syariah.

2. Sudah beroperasi sejak tahun 2010.

3. Mempublikasikan Annual Report periode 2010-2014.

4. Melakukan self assessment terkait Good Corporate Governance (GCG) periode 2010-2014.

5. Laporan keuangannya sudah diaudit oleh lembaga independen 


\section{Teknik Pengumpulan Data}

Data diperoleh dari publikasi resmi Bank Umum Syariah dan Unit Usaha Syariah yang bersangkutan, mengenai Annual Report dari tahun 2010 sampai dengan 2014. Adapun data pendukung diperoleh melalui studi pustaka yang dilakukan dengan mengkaji buku-buku literatur, jurnal, dan makalah. Dengan tujuan untuk memperoleh landasan teoritis yang komprehensif tentang BUS maupun UUS. Media internet juga digunakan untuk memperoleh data dan informasi. Adapun internet yang digunakan untuk memperoleh data dan informasi perkembangan bank adalah Bank Indonesia (http://www.bi.go.id).

\section{Teknik Analisis Data}

Metode analisis data adalah suatu metode yang digunakan untuk mengolah hasil penelitian guna memperoleh suatu kesimpulan. Analisis data yang digunakan dalam penelitian ini adalah SEM (Structural Equation Modeling) dengan program AMOS (Analysis of Moment Structure). Penelitian ini menggunakan SEM (Structural Equation Model) yang didasarkan pada evaluasi atas adanya hubungan saling ketergantungan. SEM adalah sekumpulan teknik- teknik statistik yang memungkinkan pengujian sebuah rangkaian hubungan yang relatif rumit secara simultan. Hubungan yang rumit tersebut dapat diartikan sebagai rangkaian hubungan yang dibangun antara satu atau beberapa variabel dependen (endogen) dengan satu atau beberapa variabel independen (eksogen). Analisis dilakukan dalam empat tahap sebagai berikut.

1. Analisis Deskriptif Statistik

Menurut Ghozali (2011), statistik deskriptif akan memberian gambaran atau deskripsi suatu data yang diperoleh dari nilai rata-rata, standard deviasi, maksimum, minimum, sum, range, kurtosis dan skewness.

2. Goodness of Fit Model

Uji kesesuaian antara model teoritis dan data empiris dapat dilihat pada tingkat (Goodness-of-fit statistic). Suatu model dikatakan fit apabila kovarians matriks suatu model adalah sama dengan kovarians matriks data (observed). Model fit dapat dinilai berdasarkan pengujian berbagai index fit yang diperoleh dari AMOS berdasar atas evaluasi terpenuhinya asumsi SEM (asumsi normalitas, asumsi outlier, asumsi multicollinearity dan singularity), measurement model dan analisis full structural equation model serta kriteria goodness of fit.

Ada tiga jenis ukuran dalam goodness-of-fit, akan tetapi dalam penelitian ini hanya menggunakan dua ukuran yaitu sebagai berikut.

a. Absolut Fit Measures

Absolut Fit Measures mengukur model fit secara keseluruhan (baik model secara struktural maupun secara bersama). Mengukur Absolut Fit Measures dengan menggunakan kriteria:

1) Chi-Square

Chi-Square digunakan untuk menguji perbedaan antara matrik kovarians sampel.

2) Signifikansi Probability

Probability untuk menguji tingkat signifikansi model.

PENGARUH TINGKAT KESEHATAN BANK MENURUT RISK BASED BANK RATING TERHADAP KINERJA KEUANGAN DENGAN GOOD 
3) $C M I N / D F$

Rasio ini untuk mengukur fit yang diperoleh dari nilai Chi-Square dibagi dengan degree of freedom. Byrne mengemukakan nilai rasio ini $<2$ merupakan fit.

4) GFI (Goodness of Fit Index)

GFI adalah ukuran non statistic yang nilainya berkisar dari 0 (poor fit) sampai 1,0 (perfect fit). Nilai GFI di atas $90 \%$ sebagai ukuran good fit.

5) RMSEA (Root Mean Square Error of Approximation)

RMSEA adalah ukaran yang digunakan untuk memperbaiki kecenderungan nilai Chi-square untuk menolak model dengan sampel besar. Nilai yang diterima dalam pengukuran ini berkisar antara 0,05 sampai 0,08 .

b. Incremental Fit Measures

Incremental fit measures membandingkan proposed model dengan baseline modelyang sering disebut dengan null model. Mengukur Incremental fit measures menggunakan kriteria sebagai berikut.

1) AGFI (Adjusted Goodness of Fit)

AGFI merupakan pengembangan dari GFI yang disesuaikan dengan degree of freedom untuk proporsi model dengan degree of reedom untuk null model. Tingkat derajat penerimaan adalah sama dengan atau lebih besar dari 0,90.

2) TLI (Tucker Lewis Index)

Ukuran ini menggabungkan ukuran parsimony ke dalam index komparasi antara proposed model dan null model. Nilai TLI yang direkomendasikan adalah $\geq 0,90$.

3) NFI (Normed Fit Index)

NFI merupakan ukuran perbandingan antara porposed model dan null model. Nilai NFI direkomendasikan $\geq 0,90$.Secara ringkas cutt off value dari Goodness of Fit Index dapat dilihat dalam tabel 4.

\section{Uji Hipotesis}

Hipotesis yang penulis gunakan dalam penelitian ini adalah hipotesis asosiatif. Hipotesis asosiatif merupakan dugaan sementara tentang adanya hubungan antar variabel dalam populasi yang akan diuji melalui hubungan antar variabel dari sampel yang diambil dalam populasi tersebut (Sugiyono, 2013). Untuk mencari hubungan antara dua variabel atau lebih tersebut dilakukan dengan menghitung korelasi antar variabel yang akan dicari hubungannya.

\section{Uji Pengaruh Langsung dan Tidak Langsung}

Uji ini dilakukan untuk mengetahui apakah variabel intervening dapat melaksanakan perannya dalam menaikkan atau menurunkan pengaruh variabel independen terhadap variabel dependen.

Jurnal Akuntansi Indonesia 


\section{PEMBAHASAN}

\section{Analisis Deskriptif Statistik}

Statistik deskriptif digunakan untuk menyediakan ringkasan statistik mengenai variabel independen dan dependen dalam penelitian ini. Dalam analisis deskriptif ini akan diungkapkan distribusi data, distribusi data dikatakan normal pada tingkat signifikansi 0,01 jika critical ratio (CR) skeweness (kemiringan) atau $C R$ curtois (keruncingan) tidak lebih dari $\pm 2,58$ (Santoso, 2011:78). Hasil penelitian deskriptif statistik dapat dilihat di tabel 5.

Tabel 5 menunjukkan bahwa nilai minimum dari CAR adalah 8,1 dan nilai maksimummnya adalah 195,14 dengan nilai (Critical Ratio) c.r 22,613. Nilai tersebut menunjukkan bahwa data CAR tidak berdistribusi normal. Nilai untuk NIM, minimumnya adalah 0,8 dan maksimumnya 41,54 dengan nilai c.r sebesar 18,717. Nilai tersebut menunjukkan bahwa NIM tidak berdistribusi normal karena 18,717>2,58. Nilai BOPO, minimumnya adalah 22,27 sedangkan maksimumnya adalah 182,31 dengan c.r 1,807 yang menunjukkan bahwa BOPO berdistribusi normal. Nilai FDR, minimumnya adalah 16,98 dan maksimumnya adalah 311,48 dengan nilai c.r sebesar 8,082 yang menunjukkan bahwa FDR tidak berdistribusi normal. Nilai NPF, minimummnya adalah 0,00 sedangkan maksimumnya adalah 15,4 dengan c.r sebesar 9,167 yang menunjukkan bahwa NPF tidak berdistribusi normal. Nilai GCG, miniummnya adalah 1,00 sedangkan maksimumnya adalah 2,58 dengan c.r sebesar 0,916 yang menunjukkan bahwa GCG berdistribusi normal. Untuk nilai yang terakhir yaitu ROA, minimummnya adalah -17,22 sedangkan maksimumnya adalah 185,3 dengan c.r sebesar 46,798 yang menunjukkan bahwa data tidak berdistribusi normal.

\section{Goodness Of Fit Model}

Pengujian hipotesis akan menggunakan model untuk menilai kriteria goodness of fit dengan Structural Equation Modeling (SEM). Goodness of fit mengukur kesesuaian pengamatan atau input yang sebenarnya (kovarian atau matrik korelasi) dengan model yang diusulkan. Hubungan antara beberapa variabel dapat tergambar dalam gambar 2

Kesesuaian antara model dengan cut off value dapat dilihat dalam tabel 6, hasil dari perhitungan Goodness of Fit Model di atas menunjukkan bahwa nilai dari Chi-Square, Probabilitas, GFI, AGFI, CMIN/DF, TLI, CFI, dan RMSEA secara keseluruhan berada pada nilai fit. Sehingga, berdasarkan hasil tersebut dapat dikatakan bahwa tidak ada pengaruh yang signifikan antara input model yang didasarkan pada teori dan data penelitian dengan yang path analysis diusulkan.

\section{Uji Hipotesis}

Output struktural parameter estimates dapat digunakan untuk menguji hubungan antar variabel dalam model. Hasil pengujian struktural parameter estimasi dapat dilihat pada output estimates bagian regression weight, sedangkan keeratan hubungan antar variabel dapat dilihat pada output estimates bagian standardized regression weight.

PENGARUH TINGKAT KESEHATAN BANK MENURUT RISK BASED BANK RATING TERHADAP KINERJA KEUANGAN DENGAN GOOD 
Hasil pengujian berdasarkan tabel analisis regression weights di atas diringkas dalam tabel berikut. Hipotesis tidak diterima jika probabilitas di atas 0,05 dan nilai CR kurang dari 1,96.

Berdasarkan uji hipotesis di atas data menunjukkan bahwa NPF tidak berpengaruh secara signifikan terhadap GCG. Karena NPF merupakan ukuran jumlah kredit bermasalah yang kemungkinan tidak dapat ditagih. Nilai NPF tidak berpengaruh secara signifikan terhadap GCG karena faktor untuk menentukan GCG tidak hanya didasarkan pada pemberian kredit atau pembiayaan yang diberikan kepada masyarakat, melainkan terdapat faktor lain. Bagi Bank Umum Syariah masih terdapat 10 faktor lain yang menentukan kualitas GCG, sedangkan bagi Unit Usaha Syariah masih terdapat 4 faktor lain. Jadi karena rendahnya persentase keterlibatan NPF terhadap GCG inilah yang menyebabkan pengaruh NPF terhadap GCG tidak signifikan.

Hasil analisis data menunjukkan bahwa FDR tidak berpengaruh secara signifikan terhadap GCG. GCG merupakan ukuran tata kelola perusahaan yang baik, tata kelola perusahaan yang baik tidak selalu hanya didasarkan pada pembiayaan yang diberikan, ataupun banyaknya Dana Pihak Ketiga (DPK) yang dihimpun oleh bank. Sedangkan FDR sendiri adalah kemampuan membayar kembali deposan atas dana yang diberikannya, yang mengandalkan kredit sebagai sumber likuiditasnya. Jadi FDR hanya menunjukkan resiko profil, dan sama seperti NPF, hanya mengambil bagian satu dari 11 faktor pada Bank Umum Syariah, dan 1 dari 5 faktor pada Unit Usaha Syariah.

Hasil analisis data menunjukkan bahwa CAR berpengaruh secara positif dan signifikan terhadap GCG. Peningkatan rasio kecukupan modal atau CAR dapat meningkatkan nilai GCG. Akan tetapi hubungan tersebut tidak dapat digunakan untuk mengukur tingkat kesehatan bank menurut Risk Based Bank Rating, karena semakin tinggi nilai GCG berarti menunjukkan tingkat tata kelola BUS atau UUS yang semakin tidak baik.

Hasil analisis menunjukkan bahwa BOPO tidak berpengaruh secara signifikan terhadap GCG. Karena sama dengan faktor sebelumnya yaitu NPF dan FDR, bahwa BOPO hanya salah satu dari faktor yang menentukan penilaian GCG. Jadi nilai tersebut tidak dapat mempengaruhi secara signifikan terhadap nilai komposit yang berasal dari self assessment BUS atau UUS yang bersangkutan. Hasil analisis menunjukkan bahwa nilai NIM tidak berpengaruh secara signifikan terhadap GCG. Karena seharusnya NIM dan GCG harus bekerja sama untuk meningkatkan kesehatan bank, yang pada akhirnya akan meningkatkan kinerja BUS atau UUS yang direfleksikan dalam ROA.

Hasil analisis menunjukkan bahwa GCG tidak berpengaruh secara signifikan terhadap ROA. Hasil penelitian ini bertentangan dengan penelitian terdahulu yang dilakukan oleh Halviani (2014), yang menyatakan bahwa Good Corporate Governance sebagai variabel moderasi dapat memperkuat hubungan antara ROA terhadap DPR. Hasil analisis menunjukkan bahwa tidak ada pengaruh signifikan antara FDR terhadap ROA. Hal ini bertentangan dengan penelitian terdahulu oleh Gelos (2006), yang menyatakan bahwa FDR berpengaruh positif terhadap ROA, karena penyaluran dana melalui pembiayaan yang semakin besar kepada masyarakat dapat meningkatkan pendapatan BUS atau UUS. Perbedaan hasil ini disebabkan karena pada penelitian terdahulu tidak memperhitungkan NPF. Padahal NPF adalah total pembiayaan bermasalah, jadi apabila pengaruh NPF tidak diperhitungkan maka tidak akan dapat menghitung pengaruh FDR terhadap ROA secara tepat. 
Hasil analisis menunjukkan bahwa BOPO berpengaruh secara negatif signifikan terhadap ROA. Artinya apabila terjadi penurunan BOPO maka akan meningkatkan ROA. Hal ini sejalan dengan penelitian yang dilakukan Mawardi (2005), menyimpulkan bahwa BOPO berpengaruh negatif terhadap kinerja bank yang diproksikan dengan ROA. Dalam penelitian ini semakin tinggi rasio biaya terhadap pendapatan operasional BUS atau UUS maka akan menurunkan nilai ROA, selama tidak ada faktor lain yang mengganggu seperti pembentukan cabang BUS atau UUS yang baru yang tetap dapat meningkatkan ROA melalui profitabilitasnya.

Hasil analisis menunjukkan bahwa NPF tidak berpengaruh secara signifikan terhadap ROA. Hasil penelitian ini bertentangan dengan penelitian terdahulu oleh Edhi (2009) dan Heriyanto (2009) NPF berpengaruh negatif terhadap profitabilitas (ROA) perbankan. Hal ini kemungkinan besar disebabkan karena NPF tidak secara langsung mempengaruhi ROA, akan tetapi NPF harus dikombinasikan atau harus melalui FDR dalam mempengaruhi ROA. Akan tetapi kelemahan dari penelitian ini adalah belum ada path analysis untuk hubungan NPF dan FDR terhadap ROA.

Hasil analisis menunjukkan bahwa NIM tidak berpengaruh secara signifikan terhadap ROA. Hasil ini bertentangan dengan penelitian terdahulu oleh Usman (2003), yang menunjukkan bahwa NIM berpengaruh positif terhadap ROA dikarenakan ROA dipengaruhi oleh laba. Hal ini kemungkinan disebabkan karena sampel penelitian Unit Usaha Syariah. Pembagian permodalan dalam bank konvensional dan unit usaha syariah belum terbagi dengan jelas, begitupun dengan aktiva produktif dari unit usaha syariah.

Berdasarkan tabel 10 uji pengaruh langsung dan tidak langsung di atas menunjukkan bahwa Pengaruh langsung NPF terhadap ROA adalah sebesar 0,093. Pengaruh tidak langsungnya, yakni NPF berpengaruh terhadap ROA melalui GCG sebesar -0,003. Sehingga hasil ini menunjukkan bahwa GCG tidak mampu memoderasi hubungan antara NPF dengan ROA, karena hasil estimasi pengaruh langsung lebih tinggi daripada pengaruh tidak langsung. Hal ini disebabkan karena masyarakat penerima pembiayaan bukan merupakan pihak yang memperhatikan tata kelola perusahaan, melainkan hanya pihak berkewajiban menerima dan mengembalikan pembiayaan.

Pengaruh langsung FDR terhadap ROA sebesar-0,102. Pengaruh tidak langsung, FDR mempengaruhi ROA melalui GCG sebesar -0,003. Hasil ini menunjukkan bahwa GCG mampu memoderasi hubungan FDR terhadap ROA. Pengaruh tidak langsung CAR terhadap ROA melalui GCG adalah sebesar -0,005 yang berarti negatif signifikan $(-0,005<0,005)$. Hasil ini tidak dapat dibandingkan dengan pengaruh langsung untuk mengetahui apakah variabel GCG mampu memoderasi hubungan antara CAR dengan ROA, karena tidak dibuat jalur analisis hubungan langsung antara CAR dengan ROA.

Pengaruh langsung BOPO terhadap ROA adalah sebesar -0,242. Pengaruh tidak langsung, BOPO mempengaruhi ROA melalui GCG dengan nilai sebesar-0,001. Hasil ini menunjukkan bahwa pengaruh moderasi GCG bernilai negatif signifikan $(-0,001<0,005)$. GCG mampu memoderasi hubungan antara BOPO terhadap ROA, karena nilai pengaruh langsung BOPO terhadap ROA lebih kecil daripada pengaruh tidak langsung BOPO terhadap ROA melalui GCG. Hal ini disebabkan karena pengaturan manajeman yang baik pada BUS atau UUS dapat membuat kebijakan dalam mengendalikan biaya yang mungkin timbul dalam kegiatan operasional.

Pengaruh langsung NIM terhadap ROA adalah sebesar -0,079. Sedangkan pengaruh tidak langsung NIM

PENGARUH TINGKAT KESEHATAN BANK MENURUT RISK BASED BANK RATING TERHADAP KINERJA KEUANGAN DENGAN GOOD CORPORATE GOVERNANCE SEBAGAI VARIABEL PEMODERASI PADA BANK UMUM SYARIAH DAN UNIT USAHA SYARIAH DI INDONESIA 
terhadap ROA melalui GCG adalah sebesar -0,002. Hasil ini menunjukkan bahwa GCG mampu memoderasi hubungan antara NIM dengan ROA. Hal ini karena penerapan GCG yang baik dala, BUS atau UUS dapat meningkatkan kemampuan pengelolaan aktiva produktif perbankan untuk menghasilkan pendapatan bunga atau bagi hasil bersih.

\section{KESIMPULAN DAN SARAN}

Berdasarkan hasil penelitian yang dilakukan dapat diketahui bahwa dapat diketahui bahwa secara simultan tingkat kesehatan bank umum syariah yang diukur menggunakan NPF, FDR, BOPO, NIM, dan CAR denganGCG sebagai variabel inetervening mampu berpengaruh terhadap kinerja keuangan (ROA). Sedangkan secara parsial hanya variabel CAR yang mempengaruhi GCG, dan variabel BOPO yang mempengaruhi ROA. Sedangkan variabel intervening GCG mampu memoderasi variabel FDR, BOPO, dan NIM dalam mempengaruhi ROA.

Berdasarkan penelitian dan kesimpulan di atas, penulis dapat memberikan saran bahwa bank Umum Syariah dan Unit Usaha Syariah mampu mengelola rasio biaya opersional terhadap pendapatan operasional dengan lebih baik. Karena semakin rendah BOPO berarti semakin efisien bank tersebut dalam mengendalikan biaya operasionalnya, dengan adanya efisiensi biaya maka keuntungan yang diperoleh bank akan semakin besar.

Penelitian ini juga menunjukkan bahwa GCG mampu memoderasi hubungan antara BOPO dengan ROA, sehingga seharusnya Bank Umum Syariah dan Unit Usaha Syariah lebih memperhatikan tata kelola perusahaan. Karena dengan manajemen dan pengawasan yang baik maka biaya yang mungkin timbul dari kegiatan operasional dapat dikontrol sehingga meningkatkan profitabilitas. Disamping itu GCG juga perlu diterapkan karena digunakan untuk meyakinkan para pemegang kepentingan mengenai dana yang ditanamkannya di BUS atau UUS. Diharapkan nantinya Bank Umum Syariah dengan penerapan GCG yang baik dapat meningkatkan ROA, sehingga dapat meningkatkan asset perusahaan nantinya dan menambah jumlah pembiayaan ke masyarakat. Bagi Unit Usaha Syariah diharapkan dapat segera menjadi bank independen apabila nilai ROA bergerak positif dan mengalami peningkatan.

\section{DAFTAR PUSTAKA}

Adila, Raisa. “Lembaga Keuangan Syariah RI Tempati Peringkat Ketiga Dunia”. 2015. http://www.okezone.com (diakses pada 05/12/15 pukul 14.39).

Archer, Simon dan Rifaat Ahmed A.K. 2009. Profit-Sharing Investment Accounts in Islamic Bank: Regulatory Problem and Possible Solutions. Journal of Banking Regulation,Vol.10,4.

Arthesa, Ade dan Edia Handiman. 2009. Bank dan Lembaga Keuangan Bukan Bank. PT Indeks, Jakarta.

Bank Indonesia. 2010. Surat Edaran Bank Indonesia No. 12/13/DPbS - Pelaksanaan Good Corporate Governance bagi Bank Umum Syariah dan Unit Usaha Syariah. http://www.bi.go.id/. (diakses pada 28/12/15 pukul 16.26). 
Bank Indonesia. 2015. Statistik Perbankan Syariah. http://www.bi.go.id/.(diakses pada 28/12/15 pukul 16.25).

BI Rate. 2015. http://www.bi.go.id/ (diakses pada 08/12/15 pukul 10.24).

Dendawijaya, Lukman. (2009). Manajemen Perbankan. Ghalia Indonesia, Jakarta.

Dincer, Hasan. Gulsah Gencer, Nazife Orhan, dan Kevser Sahinbas. 2011. A performance evaluation of the Turkish

Banking Sector After Global Crisis via CAMEL Ratios. Procedia Social and Behavioral Sciences 24, hal 15301545.

Edhi Catur, Bayu. 2009. Analisis Pengaruh Rasio CAR, BOPO, NIM, LDR, NPL, PPAP, dan PLO terhadap ROA (studi pada Bank Umum di Indonesia periode 2004-2007). Tesis Magister Manajemen Universitas Diponegoro. Semarang.

Gelos, R Gaston. 2006. Banking Spreads in Latin America. IMF Working Paper, International Monetary Fund.

Ghozali, Imam. 2007. Pengaruh CAR, FDR, BOPO, dan NPL Terhadap Profitabilitas Bank Syariah Mandiri (Januari: 2004-Oktober: 2006. Skripsi Fakultas Ekonomi, UII, Yogyakarta.

Ghozali, Imam. (2011). Aplikasi Analisis Multivariate Dengan Program SPSS. Semarang: Badan Penerbit Universitas Diponegoro.

Gugler \& Yurtoglu. 2003. Corporate governance and dividend pay-out policy in Germany. European Economic Review 47 (2003) 731 - 758. https://www.wu.ac.at (diakses pada 28/12/2015 pukul 14.02).

Halviani, Made Dwi. 2014. Pengaruh Moderasi Good Corporate Governance Pada Return On Asset Dan Dividend Payout Ratio. E-Jurnal Akuntansi Universitas Udayana 7.2 (2014): 332- 344 (diakses pada 28/12/2015).

Hempel, George H. Alan B. Coleman, Donald G. Simonson. 1986. Bank Management Text And Cases. John Wilry and Sons.

Heriyanto, Rickson. 2009. Analisis Pengaruh CAR, NIM, LDR, NPL, BOPO, KAP terhadap ROA (pada Bank Pemerintah di Indonesia periode tahun 2004-2008). Tesis Magister Manajemen Universitas Diponegoro. Semarang.

Husnan, Suad. 1998. Manajemen Keuangan - Teori dan Penerapan. Buku 2, BPFE Yogyakarta.

Jakarta : Djambatan.

Januarti, Indra. 2002. Variabel Proksi CAMEL dan Karakteristik Bank Lainnya Untuk Memprediksi Kebangkrutan Bank di Indonesia. Jurnal Bisnis Strategi. Vol.10. Desember. Hal 1-26.

Mawardi, Wisnu. 2005. Analisis Faktor Faktor yang Mempengaruhi Kinerja Keuangan Bank Umum di Indonesia (Studi Kasus pada Bank Umum dengan Total Asset Kurang dari 1 Triliun). Jurnal Bisnis Strategi, Vol.14, No.1, Juli, pp.83-94.

Muhamad. 2005. Manajemen Bank Syariah. Yogyakarta: UUP AMPY KPN

Muhari, Syafaat. 2013. "Tingkat Efisiensi Bank Pembiayaan Rakyat Syariah (BPRS) di Indonesia". Bahan-Bahan

Terpilih dan Hasil Riset Terbaik Forum Riset Perbankan Syariah VI, Bank Indonesia, IAEI dan Universitas

Lambung Mangkurat.

Muljono, Teguh Pudjo. 1999. Bank Budgeting.Yogyakarta: BPFE.

Mulyono, Teguh Pudjo. 1995. Analisis Laporan Keuangan Untuk Perbankan,

Nusantara, Ahmad Buyung. 2009. Analisis Pengaruh NPL, CAR, LDR, dan, BOPO Terhadap Profitabilitas Bank

PENGARUH TINGKAT KESEHATAN BANK MENURUT RISK BASED BANK RATING TERHADAP KINERJA KEUANGAN DENGAN GOOD 
(Perbandingan Bank Umum Go Publik dan Bank Umum Non Go Publik di Indonesia Periode Tahun 20052007). Program Studi Magister Manajemen Universitas Diponegoro. Semarang.

Otoritas Jasa Keuangan. 2013. Penilaian Tingkat Kesehatan Bank Umum Syariah dan Unit Usaha Syariah. Jakarta.

Otoritas Jasa Keuangan. Peraturan Otoritas Jasa Keuangan Nomor 8/Pojk.03/2014. http://www.ojk.go.id/. (diakses pada 28/12/15 pukul 16.23).

Rahab, Amiruddin al. 2008. Kekerasan Komunal di Indonesia: Sebuah Tinjauan Umum. Jurnal Dignitas .Volume V No. 1.

Schleifer, A., dan R.W. Vishny. 1977. Large Shareholders and Corporate Control, Journal of Political Economy 94 (31).

Sugianto, FX., Prasetiono, dan Teddy Haryanto. Manfaat Indikator-indikator Keuangan dalam Pembentukan Model Prediksi Kondisi Kesehatan Bank. Jurnal Bisnis Strategi, Vol. 10, Desember, 2002, h. 11-26.

Sugiyono. 2013. Statistika untuk Penelitian. Bandung: Alfabeta.

Sulistyowati, Agnes. 2014. Pengaruh Struktur Modal Terhadap Kebijakan Dividend (Studi pada Perusahaan

yang Terdaftar di Bursa Efek Indonesia Periode Tahun 2010-2012). Jurnal Administrasi Bisnis (JAB) Vol. 8 No. 2 Maret 2014 administrasi bisnis.studentjournal.ub.ac.id.

Syakhroza, Akhmad. “Model Komisaris untuk Efektifitas GCG di Indonesia”, Usahawan No. 05, Mei 2004.

Tainio, Risto, Pekka J. Korhonen, Timo J. Santalainen. 2000. In Search of Explanation for Bank Performance - Some Finnish Data. Organization Studies, 12/3. p : 425-450.

Usman, Bahtiar. 2003. Analisis Rasio Keuangan Dalam Memprediksi Perubahan laba Pada Bank-Bank di Indonesia. Media Riset Bisnis dan Manajemen, Vol.3, No.1.

Wijayanti, Feb Tri dkk. 2011. "Pengaruh Corporate Social Responsibility terhadap kinerja keuangan perusahaan”. SNA XIV. 


\section{LAMPIRAN}

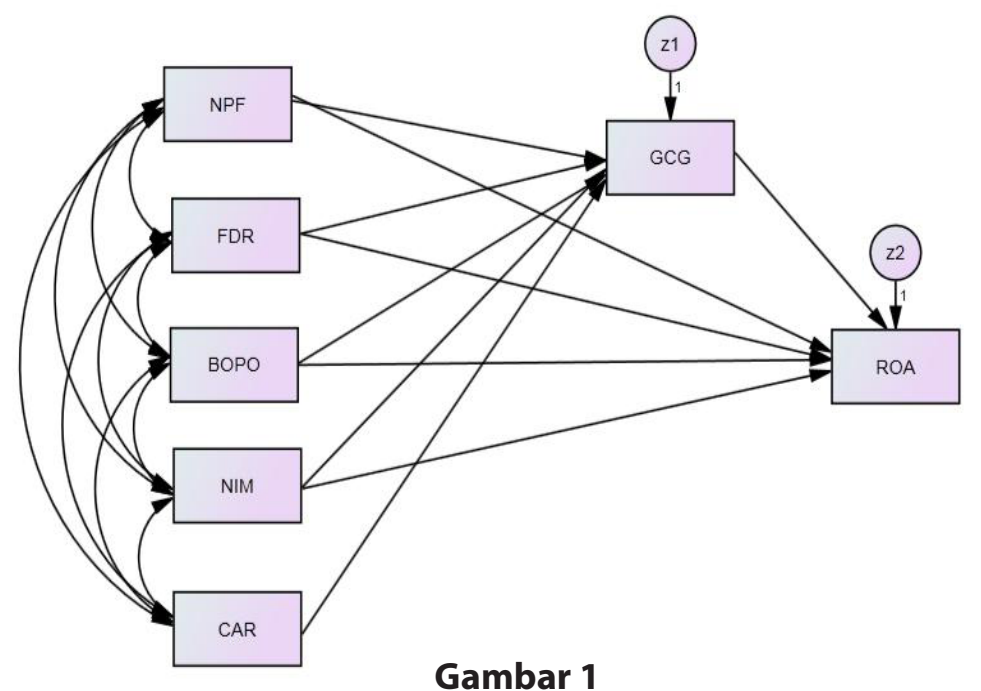

Keterangan :

NPF : Non Performing Financing

FDR : Financing to Deposit Ratio

BOPO : Biaya Operasional terhadap Pendapatan Operasional

NIM : Net Interest Margin

CAR : Capital Adequacy Ratio

GCG : Good Corporate Governance

ROA : Return On Asset

Diagram Path

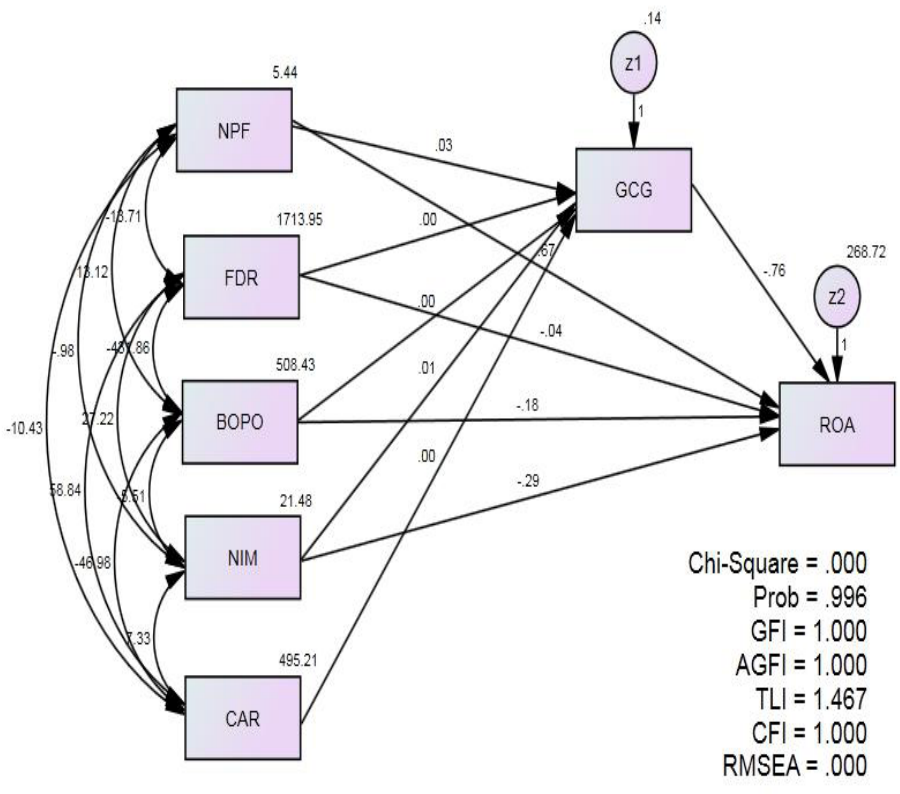

Gambar 2

Goodness of Fit Model 
Tabel 1

Rasio Keuangan Bank Umum Syariah dan Unit Usaha Syariah

\begin{tabular}{|c|c|c|c|c|c|c|}
\hline Rasio & 2010 & 2011 & 2012 & 2013 & 2014 & 2015 \\
\hline NPF & $3.02 \%$ & $2.52 \%$ & $2.22 \%$ & $2.62 \%$ & $4.33 \%$ & $4.62 \%$ * \\
\hline FDR & $89.67 \%$ & $88.94 \%$ & $100.00 \%$ & $100.32 \%$ & $91.50 \%$ & $94.18 \% *$ \\
\hline BOPO & $80.54 \%$ & $78.41 \%$ & $74.97 \%$ & $78.21 \%$ & $94.16 \%$ & $93.79 \%$ \\
\hline CAR & $16.25 \%$ & $16.63 \%$ & $14.13 \%$ & $14.42 \%$ & $15.74 \%$ & $14.06 \%$ * \\
\hline ROA & $1.67 \%$ & $1.79 \%$ & $2.14 \%$ & $2.00 \%$ & $0.79 \%$ & $1.08 \%$ * \\
\hline
\end{tabular}

Sumber: Otoritas Jasa Kuangan (2015), diolah *: Data sampai April 2015

Tabel 2

Definisi dari variabel penelitian ditunjukkan dalam tabel di bawah ini.

\begin{tabular}{|c|c|c|c|}
\hline Variabel & Definisi & Skala & Sumber \\
\hline Return on Assets (ROA) & $\begin{array}{l}\text { Perbandingan antara laba sebelum pajak dengan rata- } \\
\text { rata total asset dalam satu periode }\end{array}$ & Rasio & $\begin{array}{l}\text { Bank Indonesia } \\
(2004)\end{array}$ \\
\hline $\begin{array}{l}\text { Non Performing } \\
\text { Financing (NPF) }\end{array}$ & $\begin{array}{l}\text { NPF adalah jumlah kredit yang bermasalah dan } \\
\text { kemungkinan tidak dapat ditagih. Semakin besar nilai } \\
\text { NPF maka semakin buruk kinerja bank tersebut. }\end{array}$ & Rasio & $\begin{array}{l}\text { Muhammad } \\
(2005)\end{array}$ \\
\hline $\begin{array}{l}\text { Financing to Deposit } \\
\text { Ratio (FDR) }\end{array}$ & $\begin{array}{l}\text { Rasio yang digunakan untuk mengukur likuiditas suatu } \\
\text { bank dalam membayar kembali penarikan dana yang } \\
\text { dilakukan deposan dengan mengandalkan kredit yang } \\
\text { diberikan sebagai sumber likuiditasnya. }\end{array}$ & Rasio & Arthesa (2009) \\
\hline $\begin{array}{l}\text { Biaya Operasional } \\
\text { terhadap Pendapatan } \\
\text { Operasional (BOPO) }\end{array}$ & $\begin{array}{l}\text { Rasio biaya operasional digunakan untuk mengukur } \\
\text { tingkat efisiensi dan kemampuan bank dalam } \\
\text { melakukan kegiatan operasi. Semakin rendah } \\
\text { BOPO berarti semakin efisien bank tersebut dalam } \\
\text { mengendalikan biaya operasionalnya. }\end{array}$ & Rasio & $\begin{array}{l}\text { Dendawijaya } \\
(2000)\end{array}$ \\
\hline $\begin{array}{l}\text { Net Interest Margin } \\
\text { (NIM) }\end{array}$ & $\begin{array}{l}\text { Salah satu proksi dari resiko pasar yang dapat diukur } \\
\text { dengan selisih antara suku bunga pendanaan (funding) } \\
\text { dengan suku bunga pinjaman diberikan (lending) atau } \\
\text { dalam bentuk absolute, yang merupakan selisih antara } \\
\text { total biaya bunga pendanaan dengan total biaya bunga } \\
\text { pinjaman. }\end{array}$ & Rasio & BI No 5/2003 \\
\hline $\begin{array}{l}\text { Capital Adequacy Ratio } \\
\text { (CAR) }\end{array}$ & $\begin{array}{l}\text { Rasio yang menunjukkan sampai sejauh mana } \\
\text { kemampuan permodalan suatu bank untuk mampu } \\
\text { menyerap risiko kegagalan kredit yang mungkin terjadi. }\end{array}$ & Rasio & Muljono (1999) \\
\hline $\begin{array}{l}\text { Good Corporate } \\
\text { Governance (GCG) }\end{array}$ & $\begin{array}{l}\text { Suatu mekanisme tata kelola organisasi secara baik } \\
\text { dalam melakukan pengelolaan sumber daya organisasi } \\
\text { secara efisien, efektif, ekonomis ataupun produktif } \\
\text { dengan prinsip-prinsip keterbukaan, akuntabilitas, } \\
\text { pertanggungjawaban, independen, dan adil dalam } \\
\text { rangka mencapai tujuan organisasi. }\end{array}$ & & $\begin{array}{l}\text { Syakhroza } \\
(2008)\end{array}$ \\
\hline
\end{tabular}


Tabel 4.

Cut Off Value Goodness of Fit Index

\begin{tabular}{|l|l|}
\hline \multicolumn{1}{|c|}{$\begin{array}{c}\text { Goodness of Fit } \\
\text { Index }\end{array}$} \\
\hline X2-Chi Square & Diharapkan Kecil \\
\hline Significance Probability & $\geq 0,05$ \\
\hline RMSEA & $\leq 0,08$ \\
\hline GFI & $\geq 0,90$ \\
\hline AGFI & $\geq 0,90$ \\
\hline CMIN/DF & $\leq 2,00$ \\
\hline TLI & $\geq 0,95$ \\
\hline CFI & $\geq 0,95$ \\
\hline
\end{tabular}

Tabel 5

Statistik Deskriptif dari Variabel Penelitian

\begin{tabular}{l|rrrrrr}
\hline Variable & $\min$ & $\max$ & skew & c.r. & kurtosis & c.r. \\
\hline CAR & 8.100 & 195.140 & 4.956 & 22.163 & 30.832 & 68.943 \\
NIM & .800 & 41.540 & 4.185 & 18.717 & 26.115 & 58.395 \\
BOPO & 22.270 & 182.310 & .404 & 1.807 & 3.747 & 8.378 \\
FDR & 16.980 & 311.480 & 1.807 & 8.082 & 5.629 & 12.586 \\
NPF & .000 & 15.400 & 2.050 & 9.167 & 6.906 & 15.441 \\
GCG & 1.000 & 2.580 & .205 & .916 & -.658 & -1.472 \\
ROA & -17.220 & 185.300 & 10.464 & 46.798 & 110.173 & 246.354 \\
Multivariate & & & & & 181.949 & 88.782
\end{tabular}

Tabel 6

Perhitungan Goodness of Fit Model

\begin{tabular}{lccc}
\hline \multicolumn{1}{c}{ Good of Fit Index } & Cut-Off Value & Hasil Analisis & Keterangan \\
\hline X 2- Chi-Square & Kecil & 0,000 & Fit \\
\hline Significance Probability & $\geq 0,05$ & 0,996 & Fit \\
\hline GFI & $\geq 0,90$ & 1,000 & Fit \\
\hline AGFI & $\geq 0,90$ & 1,000 & Fit \\
\hline CMIN/DF & $\leq 2,00$ & 0,000 & Fit \\
\hline TLI & $\geq 0,95$ & 1,467 & Fit \\
\hline CFI & $\geq 0,95$ & 1,000 & Fit \\
\hline RMSEA & $\leq 0,08$ & 0,000 & Fit \\
\hline
\end{tabular}

PENGARUH TINGKAT KESEHATAN BANK MENURUT RISK BASED BANK RATING TERHADAP KINERJA KEUANGAN DENGAN GOOD 
Tabel 7

Analisis Regression Weights

\begin{tabular}{|ll|rrrrl} 
& & Estimate & S.E. & C.R. & P & Label \\
\hline GCG <--- & NPF & .027 & .015 & 1.741 & .082 & par_1 \\
\hline GCG <--- & FDR & .002 & .001 & 1.685 & .092 & par_2 \\
GCG <--- & CAR & .005 & .002 & 2.995 & .003 & par_3 \\
\hline GCG <--- & BOPO & .001 & .002 & .581 & .561 & par_19 \\
\hline GCG <--- & NIM & .007 & .007 & .991 & .322 & par_20 \\
ROA <--- & GCG & -.763 & 3.911 & -.195 & .845 & par_4 \\
ROA <--- & FDR & -.042 & .042 & -.994 & .320 & par_5 \\
ROA <--- & BOPO & -.181 & .077 & -2.356 & .018 & par_6 \\
ROA <--- & NPF & .669 & .671 & .996 & .319 & par_7 \\
ROA <--- & NIM & -.287 & .330 & -.869 & .385 & par_18
\end{tabular}

Tabel 8

Hasil Uji Hipotesis

\begin{tabular}{|c|c|c|c|c|c|}
\hline \multicolumn{3}{|r|}{ Hipotesis } & \multirow{2}{*}{$\frac{P}{0,082}$} & \multirow{2}{*}{$\begin{array}{c}\text { CR } \\
1,741\end{array}$} & \multirow{2}{*}{$\begin{array}{c}\text { Kesimpulan } \\
\text { Ditolak }\end{array}$} \\
\hline $\mathrm{H} 1$ & : & $\begin{array}{l}\text { Non Performing Financing (NPF) berpengaruh } \\
\text { terhadap Good Corporate Governance (GCG). }\end{array}$ & & & \\
\hline $\mathrm{H} 2$ & : & $\begin{array}{l}\text { Financing to Deposit Ratio (FDR) berpengaruh } \\
\text { terhadap Good Corporate Governance (GCG). }\end{array}$ & 0,092 & 1,685 & Ditolak \\
\hline $\mathrm{H} 3$ & : & $\begin{array}{l}\text { Capital Adequacy Ratio (CAR) berpengaruh terhadap } \\
\text { Good Corporate Governance (GCG). }\end{array}$ & 0,003 & 2,995 & Diterima \\
\hline $\mathrm{H} 4$ & : & $\begin{array}{l}\text { Biaya Operasional terhadap Penghasilan Operasional } \\
\text { (BOPO) berpengaruh terhadap Good Corporate } \\
\text { Governance (GCG). }\end{array}$ & 0,561 & 0,581 & Ditolak \\
\hline $\mathrm{H} 5$ & : & $\begin{array}{l}\text { Net Interest Margin (NIM) berpengaruh terhadap } \\
\text { Good Corporate Governance (GCG). }\end{array}$ & 0,322 & 0,991 & Ditolak \\
\hline H6 & : & $\begin{array}{l}\text { Good Corporate Governance (GCG) berpengaruh } \\
\text { terhadap Return On Asset (ROA). }\end{array}$ & 0,845 & $-0,195$ & Ditolak \\
\hline $\mathrm{H} 7$ & : & $\begin{array}{l}\text { Financing to Deposit Ratio (FDR) berpengaruh } \\
\text { terhadap Return On Asset (ROA). }\end{array}$ & 0,320 & $-0,994$ & Ditolak \\
\hline $\mathrm{H} 8$ & : & $\begin{array}{l}\text { Biaya Operasional terhadap Penghasilan Operasional } \\
\text { (BOPO) berpengaruh terhadap Return On Asset (ROA). }\end{array}$ & 0,018 & $-2,356$ & Diterima \\
\hline $\mathrm{H} 9$ & : & $\begin{array}{l}\text { Non Performing Financing (NPF) berpengaruh } \\
\text { terhadap Return On Asset (ROA). }\end{array}$ & 0,319 & 0,996 & Ditolak \\
\hline $\mathrm{H} 10$ & : & $\begin{array}{l}\text { Net Interest Margin (NIM) berpengaruh terhadap } \\
\text { Return On Asset (ROA). }\end{array}$ & 0,385 & $-0,869$ & Ditolak \\
\hline
\end{tabular}


Tabel 9. Uji Pengaruh Langsung

\begin{tabular}{lll}
\hline & Pengaruh Langsung & Estimasi \\
\hline GCG & $<---N P F$ & 0,158 \\
\hline GCG & $<---$ FDR & 0,166 \\
\hline GCG & $<---$ CAR & 0,265 \\
\hline GCG & $<---$ BOPO & 0,058 \\
\hline GCG & $<---N I M$ & 0,087 \\
\hline ROA & $<---$ GCG & $-0,018$ \\
\hline ROA & $<---N P F$ & 0,093 \\
\hline ROA & $<---F D R$ & $-0,102$ \\
\hline ROA & $<---B O P O$ & $-0,242$ \\
\hline ROA & $<---N I M$ & $-0,079$ \\
\hline
\end{tabular}

Sumber : Data diolah, 2015

Tabel 10.

Uji Pengaruh Tidak Langsung

\begin{tabular}{llllll}
\hline \multicolumn{7}{l}{ Pengaruh Tidak Langsung } & & Estimasi \\
\hline ROA & $<--$ & GCG & $<--$ & NPF & $-0,003$ \\
\hline ROA & $<---$ & GCG & $<---$ & FDR & $-0,003$ \\
\hline ROA & $<--$ & GCG & $<--$ & CAR & $-0,005$ \\
\hline ROA & $<--$ & GCG & $<--$ & BOPO & $-0,001$ \\
\hline ROA & $<--$ & GCG & $<--$ & NIM & $-0,002$ \\
\hline
\end{tabular}

Sumber : Data diolah, 2015 
Jurnal Akuntansi Indonesia 